\title{
META-ANALYSIS: THE EFFECT OF DIABETES MELLITUS COMORBIDITY ON THE SEVERITY IN PATIENTS WITH COVID-19 INFECTION
}

\author{
Utin Ilma Agni Kun'ain'),Setyo Sri Rahardjo², Didik Gunawan Tamtomo²) \\ 1)Masters Program in Public Health, Universitas Sebelas Maret \\ 2)Faculty of Medicine, Universitas Sebelas Maret
}

\begin{abstract}
Background: Previous studies reported that adults with certain comorbid conditions are at increased risk for severe illness of Covid-19. The purpose of this meta-analysis study was to assess the effect of diabetes mellitus comorbidity on the severity in patients with Covid-19 infection.

Subjects and Method: Meta-analysis and systematic review was conducted by collecting articles from Pubmed, Google Scholar, and Springer Link online databases, from 2019 to 2020. Keywords used "COVID-19 and comorbidity", "COVID-19 and severity and diabetes", "comorbidity or severity or diabetes or adjusted odd ratio". The inclusion criteria were full text, using English and Indonesian language, using observational study, primary study in hospital. The study population (P) was COVID-19 patients. Intervention (I) was diabetes mellitus with comparison $(\mathrm{C})$ without diabetes mellitus. The study outcome $(\mathrm{O})$ was risk of severity. The data were analyzed using random effect model in Revman 5.3.

Results: There were 6 studies from South Korea, United States, and China. This study had high heterogeneity $\left(I_{2}=65 \%, p=0.01\right)$. DM comorbidity increased the risk of severity 2.74 times in patients with comorbidity than those without $\mathrm{DM}$ comorbidity $(\mathrm{aOR}=2.74 ; 95 \% \mathrm{CI}=1.37$ to 5.48 ; $\mathrm{p}=0.004)$.

Conclusion: Diabetes mellitus comorbidity increases the risk of severity in patients with COVID-19.
\end{abstract}

Keywords: COVID-19, severity, diabetes mellitus, comorbidity

\section{Correspondence:}

Utin Ilma Agni Kun'ain. Masters Program in Public Health, Universitas Sebelas Maret. Jl. Ir. Sutami 36A, Surakarta 57126, Central Java. Email: utinilmaagni8p@gmail.com Mobile: +628111044542 .

The $7^{\text {th }}$ International Conference on Public Health Solo, Indonesia, November 18-19, 2020 425 https://doi.org/10.26911/the7thicph.05.57 